\title{
Anticonvulsant drugs and spike propagation of motor nerves and skeletal muscle
}

\author{
H. C. HOPF \\ From the Department of Neurology, University of Göttingen, W. Germany
}

SUMMARY The propagation velocity of evoked muscle spikes was measured and normal values are presented. Carbamazepine, phenobarbitone, diazepam, and bromide-containing drugs were tested for their effect on conduction velocity of motor nerve and skeletal muscle fibres. All these drugs caused a decrease in spike propagation, both of motor nerves and skeletal muscle. After discussion of the probable mode and site of action of these drugs, it was supposed that the underlying eventsperhaps changes in permeability of excitable membranes during excitation-are an essential factor $\vec{\omega}$ in the anticonvulsant action of these drugs.

The anticonvulsant action of certain drugs must be due to their effect on the electrical activity of nervous tissue. The majority of investigations concerning these drugs have been confined to testing their influence on polysynaptic pathways and evidence has been gained that synaptic transmission is depressed (Goodman and Gilman, 1970). Some findings in experimental animals (Toman, 1949; Korey, 1951; Morrell, Bradley, and Ptashne, 1958), however, as well as clinical observations (Lovelace and Horwitz, 1968), have pointed to the fact that, for example, diphenylhydantoin might induce impairment of the function of lower motor neurones. Corresponding changes have been observed in peripheral nerves exposed to barbiturates (Heinbecker and Bartley, 1940). In both cases the site of action appears to be the excitable membrane (Thesleff, 1956; Pincus, 1972).

In 1967, and in more detail in 1968, Hopf reported on 13 patients, who developed a slight but definite decrease of motor nerve conduction velocity after treatment with high-normal doses of diphenylhydantoin. His observations were supplemented by Kauer and Hopf (1971), who demonstrated that diphenylhydantoin also reduces the conduction velocity of skeletal muscle fibres. From these findings the question arose as to whether other drugs commonly used in treatment of epilepsy might have similar 'side'effects on the electrical properties of motor nerves and muscle fibres, in particular on the propagation of their action potentials.

\section{METHODS}

Propagation velocity of evoked muscle fibre actio potentials was estimated using the method Buchthal, Guld, and Rosenfalck (1955). The stimulug current was a rectangular impulse, 0.05 to $0.1 \mathrm{msecc}$ in duration, delivered by a battery operated stimw lator. The stimulating cathode was an insulated. steel needle, $0.2 \mathrm{~mm}$ in diameter and with a bared tip of $0.5 \mathrm{~mm}$. It was placed into the muscle tissue at the distal quarter of the brachial biceps muscle. The anode was an uninsulated steel needle placed $\stackrel{\circ}{\circ}$ subcutaneously about $30 \mathrm{~mm}$ distal to the cathode.

Uninsulated steel needles with diameter of $0.2 \mathrm{~mm} \stackrel{2}{\vec{F}}$ were also used as recording electrodes. Two 'active' $\frac{0}{3}$ electrodes were placed at two sites proximal to the stimulating electrode within a distance of about $30-35 \mathrm{~mm}$ and $60-75 \mathrm{~mm}$ respectively. The corresponding indifferent electrodes were placed subcutaneously, lateral to the active electrodes at the same level and $40-50 \mathrm{~mm}$ apart.

The positions of the two active electrodes were changed until a single small muscle spike appeared $\frac{\circ}{3}$ and disappeared simultaneously at both sites while increasing and decreasing the stimulus strength? (Fig. 1). As the rise times of the evoked potentials $\frac{7}{0}$ did not exceed $0.1 \mathrm{msec}$ and their amplitudes did? not change within a certain range of stimulus $N$ strength, it was probable that the potentials corres- $N$ ponded to only one or very few activated muscle fibres (Fig. 1). 

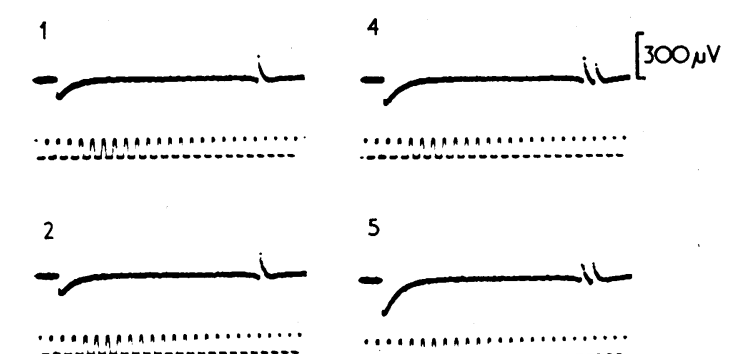

5
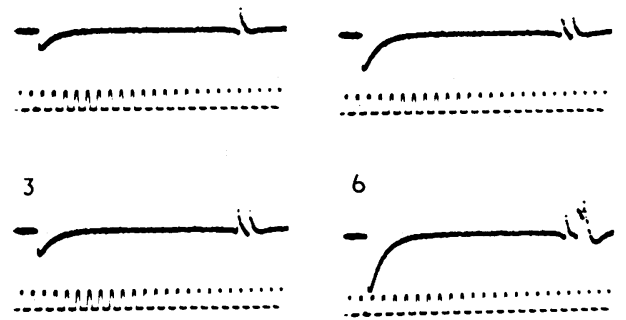

FIG. 1a. Evoked muscle spikes showing a rising phase of less than 0.2 msec and remaining unchanged with increasing stimulus strength (1-6). At 3 a second spike with longer latency is elicitated that exhibits a similar shape and behaviour. Time 1,000 $\mathrm{Hz}$.
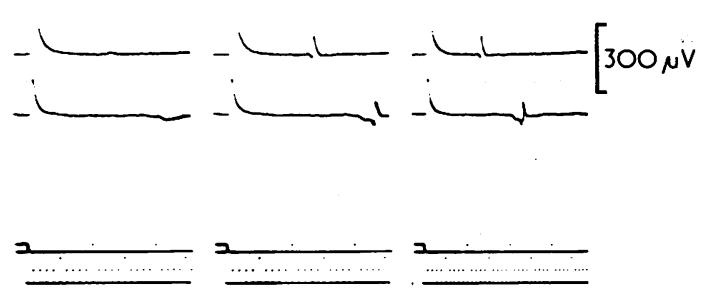

FIG. 1b. Evoked muscle spike of presumably compound character that appears synchronously at both of the recording electrodes.

Motor nerve conduction velocity was studied in the ulnar nerve. The nerve was stimulated at wrist and upper arm using pairs of surface electrodes mounted in a block of safety glass with a fixed interelectrode distance of $15 \mathrm{~mm}$. Each of the two electrodes was $8 \mathrm{~mm}$ in diameter. The stimuli were rectangular electrical shocks of 0.1 to $0.2 \mathrm{msec}$ duration adjusted to highly supramaximal intensities. The evoked response of the hypothenar muscle was picked up by surface electrodes placed in the bellytendon position.

Conduction distances for the ulnar nerve were measured while the arm was kept in the same position as during the examination - that is, fixed in a standard position with the elbow flexed to an angle of $150^{\circ}$. For the muscle fibre conduction studies, care was taken to place the stimulating and the recording electrodes in a position perpendicular to the skin. Thus, the interelectrode distance could be estimated from their points of insertion.

The muscle action potentials were recorded using a conventional $\mathbf{R}-\mathrm{C}$ coupled amplifier with a time constant of $100 \mathrm{msec}$ and a frequency band of $1 \mathrm{~Hz}$ to $10 \mathrm{kHz}$.

Tissue and skin temperature was measured twice, at the beginning and at the end of the experiment, using thermocouple elements.

All measurements were performed on students, 20 to 32 years of age. Spike propagation velocity of nerve and muscle was estimated after administration of various drugs over a period of several days. Control data were taken before the drug was administered.

\section{RESULTS}

NORMAL MOTOR NERVE AND MUSCLE FIBRE CONDUCTION VELOCITY. The maximum motor conduction velocity of the ulnar nerve was $59.4 \mathrm{~m} /$ sec (SD $4.1 \mathrm{~m} / \mathrm{sec}$ ) in 80 healthy subjects aged between 20 and 32 years. The skin temperature along the course of the nerve was $34 \cdot 3^{\circ} \mathrm{C}$ (SD $0.5^{\circ} \mathrm{C}$ ).

In 59 healthy subjects of the same age group 370 electrically evoked small muscle action potentials were evaluated. The average velocity of spike propagation was $4.22 \mathrm{~m} / \mathrm{sec}$ (SD $0.58 \mathrm{~m} / \mathrm{sec}$ ). The corresponding histogram is shown in Fig. 2. The tissue temperature was $36.3^{\circ} \mathrm{C}\left(\mathrm{SD} 0.4^{\circ} \mathrm{C}\right)$ when the examination started and $35.9^{\circ} \mathrm{C}\left(\mathrm{SD} 0.51^{\circ} \mathrm{C}\right)$ when it was finished. A delay in conduction time corresponding to the slight drop in muscle temperature was not observed.

EFFECT OF CARBAMAZEPINE (see Table) Carbamazepine (Tegretol) was tested in 18 subjects during oral administration of $1,000 \mathrm{mg}$ a day. After a period of five days the maximum motor conduction velocity of the ulnar nerve was significantly decreased from $60.9 \mathrm{~m} / \mathrm{sec}$ to $56.7 \mathrm{~m} / \mathrm{sec}(\sim 7 \%)$. Muscle fibre conduction velocity was evaluated in nine subjects. The mean velocity initially was $4.61 \mathrm{~m} / \mathrm{sec}$ and after the five days period it was significantly reduced to $4.31 \mathrm{~m} / \mathrm{sec}(\sim 6.5 \%)$. Serum levels of the drug were not determined for technical reasons.

INFLUENCE OF PHENOBARBITONE (see Table) There were 29 subjects receiving phenobarbitone 


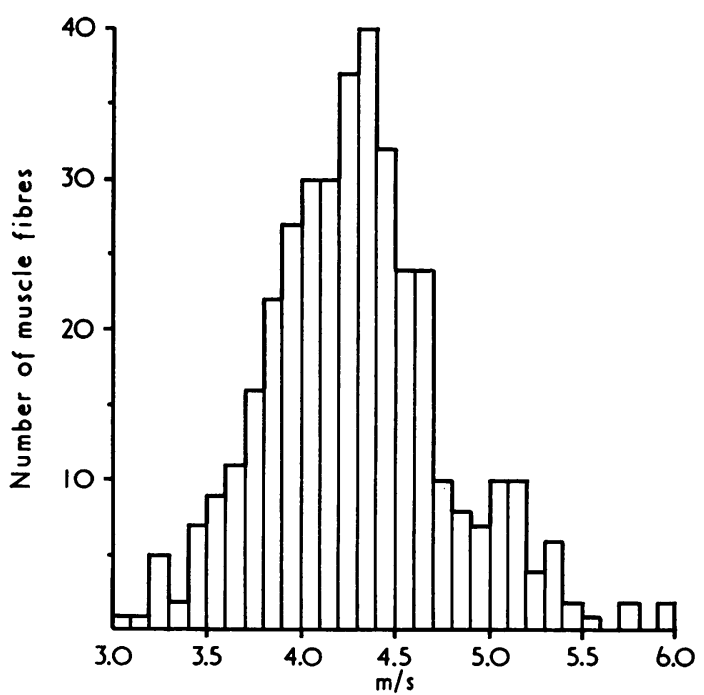

FIG. 2. Histogram of muscle fibre conduction velocity based on the evaluation of 370 spikes in 59 subjects.

orally, $300 \mathrm{mg}$ a day for five days. This drug also caused a significant reduction of motor nerve conduction velocity from $59.5 \mathrm{~m} / \mathrm{sec}$ to $56.8 \mathrm{~m} /$ $\sec (\sim 4.5 \%)$. Muscle fibre conduction velocity was measured in 22 of the 29 subjects. The mean value was found to be slowed to $4.26 \mathrm{~m} / \mathrm{sec}$ as compared with $4.56 \mathrm{~m} / \mathrm{sec}$ before drug administration $(\sim 6.5 \%)$. Again, estimations of the serum levels of the drug were not performed.
The histograms of motor nerve and muscle fibre conduction velocities are shown in Fig. 3.

ACTION OF DIAZEPAM (see Table) Diazepam (Valium) $40 \mathrm{mg}$ a day, was given to 20 subjects. $\square$ The mean motor nerve conduction velocity of $57.4 \mathrm{~m} / \mathrm{sec}$ was decreased to $54.1 \mathrm{~m} / \mathrm{sec}$ after three days of treatment $(\sim 5.5 \%)$ (Fig. 4). Muscle conduction velocity was not tested. Slowing of muscle spike propagation, however, was suggested by the fact that the duration of the negative deflection of the evoked muscle response increased from $5.41 \mathrm{msec}$ (SD 0.71 $\mathrm{msec}$ ) to $6.05 \mathrm{msec}$ (SD $0.93 \mathrm{msec}$ ). Changes of the negative deflection of the compound action potential have been accepted as indicating changes in muscle fibre conduction velocity (Desmedt, 1958).

BROMINE-CONTAINING DRUGS AND MUSCLE FIBRE CONDUCTION VELOCITY (see Table) Three patients suffering from bromide intoxicatione were tested for muscle fibre conduction velocity Serum levels were greater than $100 \mathrm{mg} \%$ where 응 the first examination was performed. The average rate of spike propagation then was $3.52 \mathrm{~m} / \mathrm{sec} ?$ After recovery the velocity was found to bes significantly faster: $4.35 \mathrm{~m} / \mathrm{sec}(\sim 19 \%)$ (Fig. 5$)$ 는

THE TEMPERATURE FACTOR Administration of the various drugs caused no decrease in tissue temperature. As can be seen from the Table

TABLE

EFFECT ON SPIKE PROPAGATION IN MOTOR NERVES AND SKELETAL MUSCLE FIBRES OF SOME ANTIEPILEPTIC DRUGS

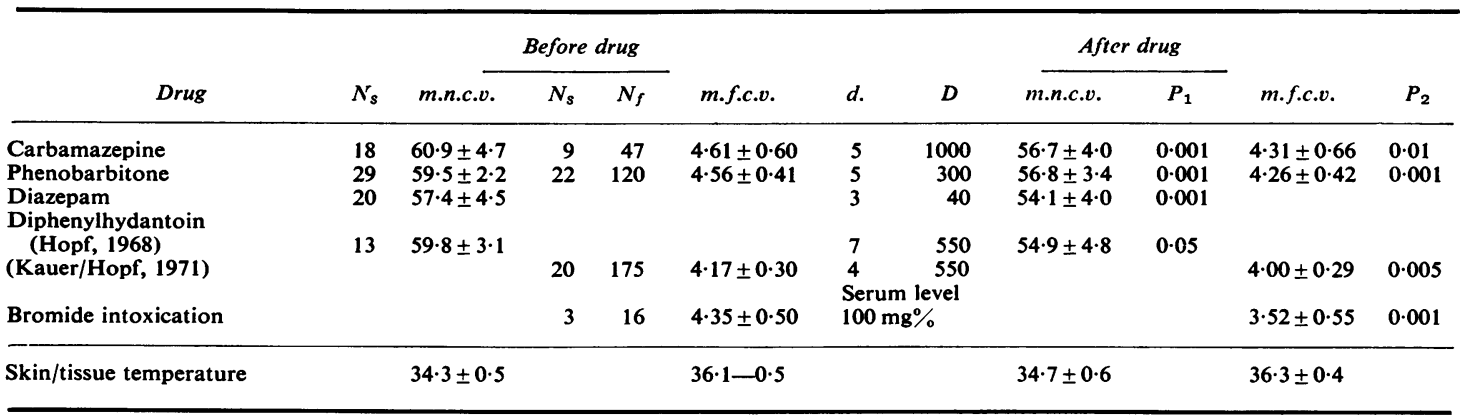

$\mathbf{N}_{\mathrm{s}}=$ number of subjects. $\mathbf{N}_{\mathrm{f}}=$ number of muscle fibres. m.n.c.v. = maximum motor nerve conduction velocity in $\mathrm{m} / \mathrm{sec} . \mathrm{m} . \mathrm{f} . \mathrm{c} . \mathrm{v} .=$ skeletal muscle fibre conduction velocity in $\mathrm{m} / \mathrm{sec}$. $\mathrm{d}=$ days of drug administration. $\mathrm{D}=$ dosage per day in $\mathrm{mg}$. $\mathrm{p}_{1}=$ statistical significance, paired $t$ test, nerve. $\mathbf{P}_{2}=$ statistical significance, paired $t$ test, muscle. Skin and tissue temperature given in ${ }^{\circ} \mathrm{C}$. 


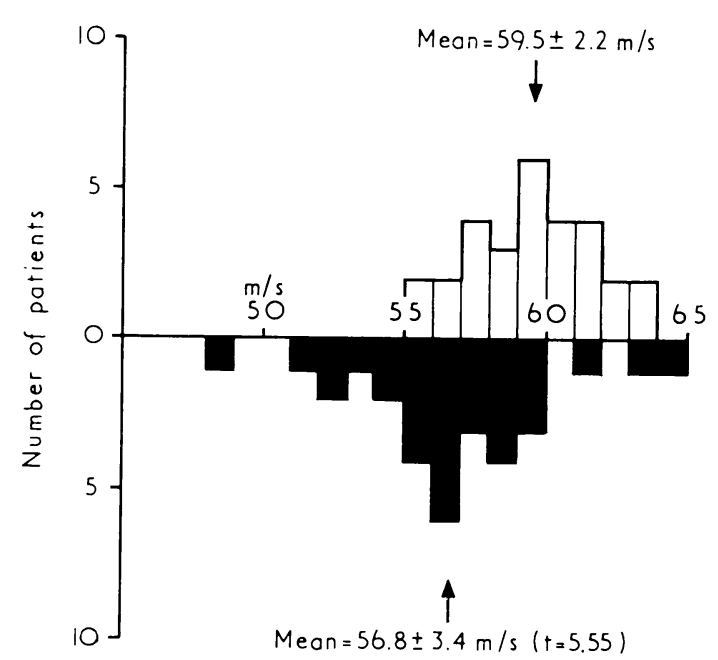

FIG. 3a. Histogram of maximum motor nerve conduction velocity.

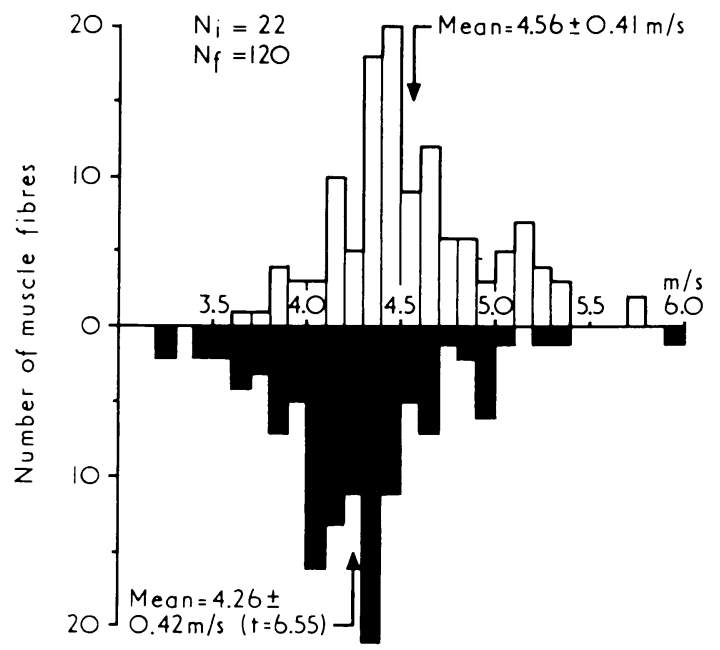

FIG. 3b. Histogram of muscle fibre conduction velocity. Values before (white columns) and after (black columns) administration of phenobarbitone at 30() $\mathrm{mg} /$ die. $N f=$ number of fibres, $N i=$ number of indiriduals. Arrows indicate the mean values.

there was actually a slight increase of the mean temperature. Thus, the changes in conduction velocities could not be attributed to a cooling effect or to a lowered blood supply which would be accompanied by a lower tissue and/or skin temperature.

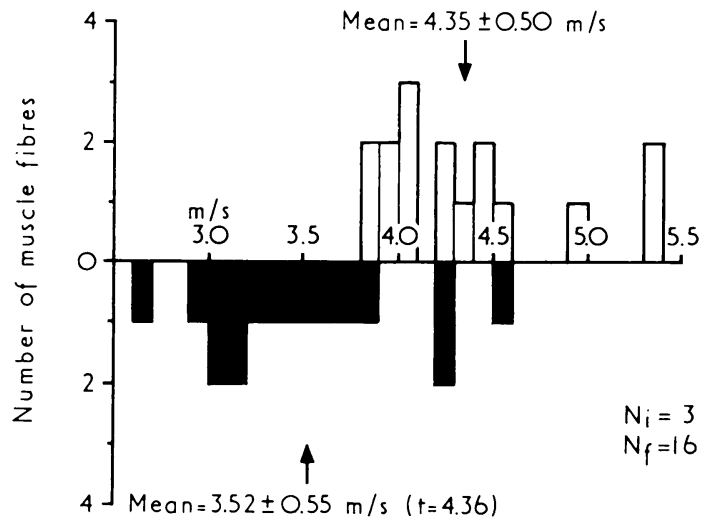

FIG. 4. Histogram of muscle fibre conduction velocity with bromide intoxication (black columns) and after recovery (white columns). For abbreviations see Fig. 3.

\section{DISCUSSION}

Our findings for the maximum motor conduction velocity of the ulnar nerve $(59.4 \mathrm{~m} / \mathrm{sec})$ agree well with the figures reported by other authors (Norris, Shock, and Wagmann, 1953; Thomas and Lambert, 1960; Lawrence and Locke, 1961; Mulder, Lambert, Bastron, and Sprague 1961; Mattson and Lecocq, 1968).

With regard to the muscle fibre conduction velocity, we do not pretend that we were measuring true single fibre spikes, although there were some features suggesting that single fibres were activated (see Methods). But at the very worst, we were dealing with the fastest component of very small muscle fibre bundles. Thus, the result might be biased by over-representation of faster velocities. This, however, would not influence the changes caused by the drugs. Fortuitous excitation of thin intramuscular motor nerve fibres by the stimulus, which was intended to be confined to the muscle parenchyma itself, seems very unlikely. The distal part of the brachial biceps muscle, where the stimulus was applied, is almost devoid of motor nerve fibres (Buchthal et al., 1955). However, if nerve rather than muscle fibre velocity were estimated, then the fibres concerned would have to be unmyelinated or very finely myelinated fibres extending over a distance of 3.5 to $7 \mathrm{~cm}$ to give the velocities obtained. To our knowledge, however, there is 
no histological evidence of such intramuscular motor nerve fibres.

The mean value of $4.22 \mathrm{~m} / \mathrm{secs}$ for muscle spike propagation velocity as reported here is slightly higher than that reported by Buchthal et al. (1955). The difference is probably due to the fact that a considerably larger number of fibres was evaluated by us. This factor probably also partly accounts for the wider range of velocities (Kauer and Hopf, 1971).

The figures of Stålberg (1966), using a different technique, show a comparable wide range of conduction velocities $(2 \cdot 0-6 \cdot 5 \mathrm{~m} / \mathrm{sec})$. The mean value, however, given by him is $0.53 \mathrm{~m} / \mathrm{sec}$ lower than the value calculated from our results. The difference between Stålberg's and our own findings is due to the fact that he found a greater number of slow conducting fibres. There are three possible explanations for this. (1) As far as can be concluded from the illustrations, Stålberg (1966) recorded from a more distal part of the muscle than we did. Thus, he might have recorded a considerable number of spikes from the tapering end of the spindle-shaped muscle fibres where the spike is expected to be propagated at a lower speed. (2) Stålberg found that conduction velocity decreased with increasing firing rates. Action potential spikes from voluntarily activated fibres were measured by him and their repetition rates varied between 5 and 20 impulses per second. In seven muscle fibres the initial values were $0.42 \mathrm{~m} / \mathrm{sec}$ faster than after repetitive activation $(4.03 \mathrm{~m} / \mathrm{sec}$ as compared with $3.6 \mathrm{~m} / \mathrm{sec}$ ). In our experiments, however, the muscle was stimulated at rates between 0.2 to $1 \cdot 0 / \mathrm{sec}$ where a decrease of the velocity does not take place. (3) It has already been mentioned that with Buchthal's method some slowly conducted spikes might have escaped detection because of being hidden in a compound evoked response.

The skin and tissue temperatures remained almost unchanged throughout the experiment. There was only a slight drop in tissue temperature of $0.4^{\circ} \mathrm{C}$ during the individual experiments. According to Hakansson (1954) this should have caused a decrease in conduction velocity of $0.04 \mathrm{~m} / \mathrm{sec}$. A corresponding delay of the muscle spike, however, was not found. We have so far been unable to explain this finding. The possibility that the differences in conduction velocity of motor nerves and muscle fibres reported here were mainly or paitly caused by an indirect effect of the tested drugs on body temperature can be ruled out, as tissue and skin temperature remained unchanged or were slightly increased.

The drug-induced decrease of conduction velocity varied between $4.5 \%$ (phenobarbitone) and $8 \%$ (diphenylhydantoin) for the fastest motor nerve fibres and between $4 \%$ (diphenylhydantoin) and $6.5 \%$ (carbamazepine) for the skeletal muscle fibres. We would like to stress that such delays in spike propagation were found with drug doses which are sometimes (carbamazepine) or commonly (diazepam, phenobarbitone) used in the treatment of epilepsy and tic douloureux.

A much greater decrease (of about $19 \%$ ) was found in the patients suffering from bromide intoxication. In these patients, however, very abnormal conditions were present, with signs of severe intoxication such as electroencephalographic (EEG) abnormalities and mental disability, and in two of them hallucinatory episodes were observed.

The drugs which are dealt with in this stude influence the electrical activity of nervous tissue (Goodman and Gilman, 1970). The influences on the EEG and/or on synaptic transmission are well known (Heinbecker and Bartley, 1940 Wikler, 1945; Stille, 1955; Caspers and Weyso meyer, 1957; Morrell et al., 1958; Domino; 1962; Esplin, 1963; Løyning, Oshime, and Yokota, 1964; Norris, Colella, and McFarlin, 1964; Schallek, Zabransky, and Kuehn, 1964; Engle, 1966; Miyahara, Esplin, and Zabloska, 1966; Ngai, Tseng, and Wang, 1966; Fromm and Killian, 1967; Kolant and Grose, 1967 Marjerrison, Jedlicki, Keough, Hrychŭk, and Poulakis, 1968; Przybyla and Wang, 1968; and others). But the mode of action on individual nerve cells has only been established so far for barbiturates and diphenylhydantoin (Blaustein, 1968; Pincus, 1972).

Blaustein tested sodium-barbitone and sodium-thiopentone in voltage clamped lobster axons and found (1) that the initial $\mathrm{Na}^{+}$and late $\mathrm{K}^{+}$currents were decreased, (2) the maximum increases of $\mathrm{Na}^{+}$and $\mathrm{K}^{+}$conductance during stimulation were reduced, (3) the rate at which the sodium conductance turns on was slowed, (4) and the final sodium conductance was shifted towards depolarization. He claimed 
that the drugs affected the axon membrane directly.

Thesleff (1956) investigated the influence of pentobarbitone on the isolated frog nerve-muscle preparation. Pentobarbitone reduced the amplitude of the miniature endplate potentials without affecting their rate of discharge, increased the threshold to electrical stimuli, and caused marked reduction of the action potential amplitude but left the resting membrane potential unaffected. His conclusions are that the ion permeability occurring during excitation is reduced by barbiturates.

As early as 1940 Heinbecker and Bartley demonstrated that when frog sciatic nerve was exposed to pentobarbitone sodium the amplitude of individual axon spikes was depressed without changing their duration, the conduction velocity was decreased, and the absolute refractory period was prolonged.

In all these experiments amounts of barbiturates were used that would cause severe intoxication in man. Our findings, however, confirm that comparable effects, though to a lesser degree, are present even with drug amounts not producing toxic symptoms.

Pincus (1972) stated that diphenylhydantoin at concentrations of $1.0 \times 10^{-4} \mathrm{M}$ to $5.0 \times 10^{-4} \mathrm{M}$ reduces the influx of ${ }^{24} \mathrm{Na}$ into stimulated lobster nerves by $40 \%$. There was no effect on the potassium uptake in stimulated nerves, nor on the sodium influx under resting conditions, and no effect on the sodium efflux in resting or stimulated nerves.

These changes in ion permeability during excitation would easily explain the action of diphenylhydantoin on nerve and muscle. Ritchie (1971) found that the size of the compound action potential of desheathed vagus nerves was reduced. Sasynik and Dresel (1968) reported that in the isolated dog heart the $\mathrm{A}-\mathrm{V}$ conduction time and propagation within the bundle of His was delayed. According to Kauer and Hopf (1971), and Hopf (1968) the propagation velocity of skeletal muscle fibres and of motor nerves is decreased.

Detailed studies have not been performed for diazepam and carbamazepine. Diazepam depresses the afterdischarge in the limbic system, blocks convulsions induced by strychnine or pentylenetetrazol, and influences the activity of the brain-stem reticular formation (Przybyla and Wang, 1968). The effect of carbamazepine on the spinal trigeminal nucleus is similar to that of diphenylhydantoin (Fromm and Killian, 1967). It has been demonstrated that both drugs reduce the conduction velocity of motor nerves and muscle fibres. Their action actually did not differ from the action of diphenylhydantoin and phenobarbitone. Thus, it seems possible that the same mechanismthe influence on ion permeability-might be involved in the effect of diazepam and carbamazepine.

In respect to the action of bromides we can only refer to the paper of Brattgård and Lindqvist (1954) who demonstrated that ${ }^{82} \mathrm{Br}$ invades nerve cells and is deposited in the cytoplasm and the nucleus. There is, however, no suggestion as to the mode of action on muscle spike propagation.

As decreasing motor nerve conduction velocity and/or muscle spike propagation is a consistent feature of all the anticonvulsant drugs tested so far, we feel that the underlying events-perhaps changes in ion permeability during excitationrepresent the essential factor in their anticonvulsant-action.

\section{REFERENCES}

Balfour, D. J., and Gilbert, J. C. (1971). Some effects of phenobarbitone on the properties of synaptosomes, British Journal of Pharmacology, 41, 400P.

Blaustein, M. P. (1968). Barbiturates block sodium and potassium conductance increases in voltage-clamped lobster axons. Journal of General Physiology, 51, 293-307.

Brattgård, S.-O., and Lindqvist, T. (1954). Demonstration of ${ }^{82} \mathrm{Br}$ in nerve cells. Journal of Neurology, Neurosurgery, and Psychiatry, 17, 11-13.

Buchthal, F., Guld, C., and Rosenfalck, P. (1955). Propagation velocity in electrically activated muscle fibres in man. Acta Physiologica Scandinavica, 34, 75-89.

Caspers, H., and Wehmeyer, H. (1957). Die Wirkung von Diphenylhydantoin auf die Krampferregbarkeit der Hirnrinde. Zeitschrift für die gesamte experimentelle Medizin, 129, 77-86.

Desmedt, J. E. (1958). Méthodes d'étude de la fonction neuromusculaire chez l'homme. Acta Neurologica Belge, 58, 977-1017.

Domino, E. F. (1962). Sites of action of some central nervous system depressants. Annual Review of Pharmacology, 2, 215-250.

Engle, H. A. (1966). The effect of diazepam (Valium) in children with cerebral palsy. Developmental Medicine and Child Neurology, 8, 661-667.

Esplin, D. W. (1963). Criteria for assessing effects of depressant drugs on spinal cord synaptic transmission, with examples of drug selectivity. Archives Internationales de Pharmacodynamie et de Thérapie, 143, 479-497.

Fromm, G. H., and Killian, J. M. (1967). Effect of some anticonvulsant drugs on the spinal trigeminal nucleus. Neurology (Minneap.), 17, 275-280. 
Goodman, L. S., and Gilman, A. (1970). The Pharmacological Basis of Therapeutics, 4th edn. Macmillan: London.

Håkansson, C. H. (1954). The propagation velocity of isolated frog muscle fibres. Acta Physiologica Scandinavica 31, Suppl. 114, 22-23.

Heinbecker, P., and Bartley, S. H. (1940). Action of ether and nembutal on the nervous system. Journal of Neurophysiology, 3, 219-236.

Hopf, H. C. (1968). Effect of diphenylhydantoin on peripheral nerves in man. (Abstract.) Electroencephalography and Clinical Neurophysiology, 25, 411.

Hopf, H. C. (1968). Über die Veränderungen der Leitfunktion peripherer motorischer Nervenfasern durch Diphenylhydantoin. Deutsche Zeitschrifte für Nervenheilkunde, 193, 41-56.

Kauer, H., and Hopf, H. C. (1971). Die Wirkung von Diphenylhydantoin auf Impulsfortleitung und Ablauf der Kontraktion in der Skelettmuskulatur des Menschen. Pharmakopsychiatrie und Neuro-Psychopharmacologie, 4, 229-238.

Kolant, H., and Grose, W. (1967). Effects of etanol and pentobrabital on release of acetylcholine from cerebral cortex slices. Journal of Pharmacology and Experimental Therapy, 158, 386-398.

Korey, S. R. (1951). Effect of dilantin and mesantoin on the giant axon of the squid. Proceedings of the Society for Experimental Biology, 76, 297-299.

Lawrence, D. G., and Locke, S. (1961). Motor nerve conduction velocity in diabetes. Archives of Neurology, 5, 483489.

Løyning, Y., Oshima, T., and Yokota, T. (1964). Site of action of thiamylal sodium on the monosynaptic spinal reflex pathway in cats. Journal of Neurophysiology, 27, 408-428.

Lovelace, R. E., and Horwitz, S. J. (1968). Peripheral neuropathy in long-term diphenylhydantoin therapy. Archives of Neurology, 18, 69-77.

Marjerrison, G., Jedlicki, S. M., Keogh, R. P., Hrychŭk, W., and Poulakakis, G. M. (1968). Carbamazepine: behavioural anticonvulsant, and EEG effects in chronically-hospitalized epileptics. Diseases of the Nervous and Mental System, 29, 133-136.

Mattson, R. H., and Lecocq, F. R. (1968). Nerve conduction velocities in fasting patients. Neurology (Minneap.), 18, 335-339.

Miyahara, J. T., Esplin, D. W., and Zabloska, B. (1966). Differential effects of depressant drugs on presynaptic inhibition. Journal of Pharmacology and Experimental Therapy, 154, 119-133.

Morrell, F., Bradley, W., and Ptashne, M. (1958). Effect of diphenylhydantoin on peripheral nerve. Neurology (Minneap.), 8, 140-144.
Mulder, D. W., Lambert, E. H., Bastron, J. A., and Sprague, R. G. (1961). The neuropathies associated with diabetes mellitus: a clinical and electromyographic study of 103 unselected diabetic patients. Neurology (Minneap.), 11 275-284.

Norris, A. H., Shock, N. W., and Wagman, I. H. (1953). Age changes in the maximum conduction velocity of motor fibres of human ulnar nerves. Journal of Applied Physiology, $5,589-593$.

Norris, F. H., Jr., Colella, J., and McFarlin, D. (1964). Effect of diphenylhydantoin on neuromuscular synapse. Neurology (Minneap.), 14, 869-876.

Ngai, S. H., Tseng, D. T. C., and Wang, S. C. (1966). Effect of diazepam and other central nervous system depressants on spinal reflexes in cats. Journal of Pharmacology and Experimental Therapy, 153, 344-351.

Pincus, J. H. (1972). Diphenylhydantoin and ion flux in lobster nerve. Archives of Neurology, 26, 4-10.

Przybyla, A. C., and Wang, S. C. (1968). Locus of central depressant action of diazepam. Journal of Pharmacology and Experimental Therapy, 163, 439-447.

Ritchie (1971) (see Pincus, 1972).

Sasyniuk, B. I., and Dresel, P. E. (1968). The effect of diphenylhydantoin on conduction in isolated bloodperfused dog hearts. Journal of Pharmacology and Experimental Therapy, 161, 191-196.

Schallek, W., Zabransky, F., and Kuehn, A. (1964). Effects of benzodiazepines on central nervous system of cat. Archives Internationales de Pharmacodynamie et de Thérapie 149, 467-483.

Stålberg, E. (1966). Propagation velocity in human muscl fibres in situ. Acta Physiologica Scandinavica, 70, Supp 287.

Stille, G. (1955). Die Wirkung der Anticonvulsiva auf daङ Rückenmark. Naunyn-Schmiedeberg's Archiv für experio mentelle Pathologie und Pharmakologie, 226, 172-179.

Thesleff, S. (1956). The effect of anesthetic agents or skeletal muscle membrane. Acta Physiologica Scandinavic $\overline{9}$ 37, 335-349.

Thomas, J. E., and Lambert, E. H. (1960). Ulnar nerve conduction velocity and $\mathrm{H}$-reflex in infants and children. Journal of Applied Physiology, 15, 1-9.

Toman, J. E. P. (1949). The neuropharmacology of antiepileptics. Electroencephalography and Clinical Neurophysiology, 1, 33-44.

Wikler, A. (1945). Effects of morphine, nembutal, ether, and eserine on two-neuron and multineuron reflexes in the cat. Proceedings of the Society for Biology and Medicine, 58, 193-196. 